\title{
PREDICTORS OF SUSTAINABLE TOURISM PERCEPTIONS: A CASE OF THE PROVINCE OF CAVITE, PHILIPPINES
}

\author{
Paul Anthony C. Notorio, Ernesto C. Mandigma Jr, Beberlee R. Desingaño, Jefferson \\ S. Buenviaje and Grace Cella R. Mejia \\ Tourism Management Department, De La Salle University - Dasmariñas Philippines
}

\begin{abstract}
This paper explored how people perceive the impacts of tourism in the Province. The paper further examined by exploring the quality of tourism resources and the intensity of tourism activity, and how these affect the perception. The study was commissioned as an input for creating a tourism development plan for the province. Results of the study show that raising the quality of natural resources and increasing land transport activity leads to a higher perception of negative tourism impacts. Increasing the activities of some industries of tourism contributes to both the positive and negative impact perception. The hotel and restaurant and the human resource have a wider effect compared to other industry and tourism resource respectively.
\end{abstract}

Keywords: sustainable tourism, tourism development, tourism impact, Cavite, tourism resources, tourism activity

\section{INTRODUCTION}

The Province of Cavite has been known as the historical capital of the Philippines. The province has many significant historical sites, the most significant of which is the Aguinaldo Shrine - the site where the first Republic of the Philippines was proclaimed. The province is also famous for the City of Tagaytay, one of the most popular tourist destinations due to the cool climate and beautiful scenery. Its proximity to Metro Manila makes the province a preferred destination for excursions and short stays. The province is popular for short hikes, unique themed restaurants, retreats and conventions, wellness, and other leisure activities.

The tourism industry of the province has been developed on few areas, particularly the City of Tagaytay and the Municipality of Kawit. The island of Corregidor, the last place to fall under the Japanese forces, is well-developed. The island is geographically part of the province of Cavite, but its tourism industry is managed by Sun Cruises, a company based in Manila. Presently, there is no provincial tourism master plan. Moreover, the impact of tourism in the province has not been studied, reflecting the study of Ballantyne, Parker \& Axelsen (2009). Several cities and municipalities have signified the intention of developing their tourism industry. Given these circumstances, it is imperative that development of tourism in the province is guided by the principles of sustainability.

Sustainable tourism encompasses the dimensions of economy, society, and physical environment. This means that trying to develop sustainable tourism in one area may differ greatly to another area due to the varying needs of the economy, society, and physical environment. An expert may affirm that the community is affected positively by tourism, but it is not necessarily felt by the majority in the community. Hence, it is important to determine people's perception on the impact of tourism (Mason, 2012). Kreag (2001) also pointed out that the people's perception on tourism impacts may be due to the quality of tourism resources. This means that developing tourism resources may lead to a higher perception of negative impacts. Another problem is that the impact is usually attributed to the tourism industry as a whole, without recognizing the fact that the tourism industry is a composition of several industries that are related, but is unique from each other. Thus, there is a need to determine which industry is perceived by the public to contribute more to a specific tourism impact. 
Tourism development, in general, often stem from two factors: what the destination can offer, and what is the existing demand. This concept is reflected in the Tourism Development Planning Guidebook for Local Government Units (Department of Tourism, 2012). In this framework, whatever negative tourism impact that may arise from the tourism development is mitigated only after the problem has occurred. An ideal framework should incorporate sustainability component before developing tourism. For destinations with a developed tourism industry but without a tourism master plan, it is even more ideal to conduct an impact assessment. This assessment should be integrated in creating the master plan. Hence, this study was commissioned to serve as an input for the creation of the tourism master plan for the Province of Cavite.

\section{CONCEPTUAL FRAMEWORK}

This study determined the quality of tourism resources (QTR), level of tourism activity (LTA), and impacts of tourism (IOT), and how the QTR and LTA affect the IOT. The study of Notorio (2010) was used as concept for to assess the QTR, namely the natural resources (NR), cultural resources (CUR), human resources (HR), and capital resources (CAR), but has added and excluded selected variables that would apply to the study area. The assessment of LTA adapted the concept outlined in the Tourism Development Planning Guidebook for Local Government Units (Department of Tourism, 2012) and the United Nations Statistics Division (2016) which categorized the variables into hotel and restaurant industry (HRI), land transport industry (LTI), water transport industry (WTI), travel service industry (TSI), and attraction industry (AI). The IOT used the triple bottom-line concept of Kreag (2001). Lastly, the IOT variables were clustered as positive economic impact (PEcI), negative economic impact (NEcI), positive socio-cultural impact (PSCI), negative socio-cultural impact (NSCI), positive environmental impact (PEnI), and negative environmental impact (NEnI).

\section{METHOD}

The respondents of the study are the residents of the Province of Cavite. The sampling frame was sourced from the National Statistics Office (2010), where the population is 3,090,691. Krejcie \& Morgan's method for sample size computation was used, generating 400 respondents. The researchers were able to distribute 721, yielding a 180.25 percent retrieval rate. Proportionate Stratified Random Sampling was used where the respondents are subdivided into seven districts, 23 cities and municipalities, and barangays.

Survey questionnaire was used incorporating the concepts. The questionnaire's content validity was examined. The questionnaire was critiqued by experts from the areas of economics, social science, and physical science. The research instrument was revised to incorporate their comments and suggestions.

Regression was used to test the hypothesis. The results were then statistically analysed using Statistical Package for Social Sciences. The results were validated by a statistician.

\section{FINDINGS}

\section{Quality of tourism resources in the Province of Cavite}

The results (Table 1) show that the natural resources (NR) were average due to the absence of rare and exceptional geological formations. The findings proves that the locals perceive that the greatest asset of the province of Cavite the unique climate of the upland areas. The finding is opposite to that of the island of Lubang whose NR are at par with that of the resources of major destinations (Notorio, 2010). However, the findings mirrors the ranking of the Philippines in terms of the quality of the natural environment, with the country ranking 92nd out of 140 countries (The World Economic Forum, 2013). 
Table 1 Quality of natural resources

\begin{tabular}{lll}
\hline & WM & VI \\
\hline climate & 2.83 & average \\
rivers & 2.82 & average \\
3.5 lakes, ponds, and springs & 2.78 & average \\
3.5 mountains and highlands & 2.78 & average \\
sea & 2.63 & average \\
beaches & 2.61 & average \\
forests & 2.56 & average \\
wildlife & 2.46 & poor \\
waterfalls & 2.41 & poor \\
diving spots & 2.32 & poor \\
caves and rock formations & 2.28 & poor \\
\hline Total & 2.61 & average \\
\hline
\end{tabular}

The CUR as shown in Table 2, were rated average because of the lack of significant development. Some variables were rated good because they are anchored on the historical advantage of the province and can compete with other famous attractions in the country.
The findings differs from the island of Lubang whose cultural resources were perceived to be less adequate (Notorio, 2010).

Table 2 Quality of cultural resources

\begin{tabular}{|c|c|c|c|}
\hline 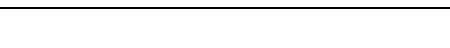 & & $W M$ & $V I$ \\
\hline \multirow{3}{*}{ 1. churches } & & 3.84 & good \\
\hline & 2.5 events and festivals & 3.52 & good \\
\hline & 2.5 historic sites & 3.52 & good \\
\hline 4. local cuisine & & 3.35 & average \\
\hline 5. way of living and traditions & & 3.32 & average \\
\hline 6. folk music and dance & & 3.17 & average \\
\hline 7. museums & & 3.08 & average \\
\hline & Total & 3.40 & average \\
\hline
\end{tabular}

The findings of Table 3 can be attributed to the difference between rural and urban workforce. The results reflects that of the findings of Bharwani \& Butt (2012) which stressed the need to improve the quality of manpower in the tourism industry. The highest rated variable, hospitality of the locals, shows that the Filipinos in general are hospitable and customer-oriented (The World Economic Forum, 2013).

Table 3 Quality of human resources

\begin{tabular}{lllc}
\hline & & $W M$ & VI \\
\hline 1. & hospitality of the locals & 3.55 & good \\
2. & management skills of the locals & 3.41 & average \\
3. available local workforce & 3.33 & average \\
4. performing artists & 3.23 & average \\
5. visual artists & 3.02 & average \\
\hline & Total & 3.31 & average \\
\hline
\end{tabular}


The CAR was rated average due to the good development in urban areas and the poor development in many rural areas. The solid waste management is particularly needs significant improvement in the municipalities of Magallanes and Silang (Cavite Provincial Planning and Development

Table 4 Quality of capital resources
Office, 2013). The high rating of the telecommunication is opposite to the data of The World Economic Forum (2013) where internet use, telephone, and mobile phone use is rated low.

\begin{tabular}{lllc}
\hline & & $W M$ & $V I$ \\
\hline 1. & telecommunication & 3.51 & good \\
2. power supply & 3.49 & average \\
3. & water supply & 3.45 & average \\
4. roads & 3.35 & average \\
$5 . \quad$ solid waste management & 3.29 & average \\
6. sewerage system & 3.25 & average \\
7. & seaports & 2.59 & average \\
\hline & & 3.25 & average \\
\hline
\end{tabular}

Cavite's reputation as the historical capital of the country is the reason why the cultural resources were rated the highest among the four categories of resources. Although the overall rating of the tourism resources were rated average which implies that development is still needed. Furthermore, the results implies that tourism should be developed around the highest rated variables. Although this argument opposes the view of Calabro \& Spina (2013) who claims that provinces with cultural resources tend to have less and seasonal visitors.

Table 5 Overall quality of capital resources

\begin{tabular}{|c|c|}
\hline & $W M$ \\
\hline 1. CUR & average \\
\hline 2. $\mathrm{HR}$ & average \\
\hline 3. CAR & average \\
\hline 4. NR & average \\
\hline Total & average \\
\hline $\begin{array}{l}\text { The HRI of the province was rated with moderate } \\
\text { activity due to the high density of hotel and } \\
\text { restaurants among tourist areas, especially in } \\
\text { Tagaytay, and few hotels and restaurants among the } \\
\text { rural and non-tourism areas. The rating was moderate }\end{array}$ & $\begin{array}{l}\text { despite the fact that the province has more } \\
\text { accommodation establishments among all the } \\
\text { provinces in the region (Department of Tourism, June } \\
\text { 2012). The high ranking of the restaurant industry } \\
\text { mirrors that of the Department of Tourism \& } \\
\text { USAID's (2014) report which shows that food and } \\
\text { beverage services has the most number of } \\
\text { establishments among registered tourism } \\
\text { establishments within Metro Manila. }\end{array}$ \\
\hline
\end{tabular}

Table 6 LTA of HRI

\begin{tabular}{|c|c|c|}
\hline & $W M$ & $V I$ \\
\hline 1. Restaurants & 4.12 & moderate \\
\hline 2. hotels and resorts & 3.74 & moderate \\
\hline 3. bars & 3.56 & moderate \\
\hline 4. motels, camps and other short-stay accommodations & 3.44 & Low \\
\hline Total & 3.72 & Moderate \\
\hline
\end{tabular}


The findings of Table 7 revealed that the tourist destinations of the province are accessed either by private or public transport, due to the few activity of the tourist transport. These findings are contradicts Table 7 LTA of LTI the high ranking of the country in LTI (The World Economic Forum, 2013).

\begin{tabular}{llll}
\hline & & $W M$ & VI \\
\hline 1. & small boats & 2.45 & very low \\
2. other tourist water transport (kayaks, rafts, etc.) & 2.20 & very low \\
$3 . \quad$ yachts & 2.05 & very low \\
4. & ferries & 2.04 & very low \\
\hline & Total & 3.72 & Very Low \\
\hline
\end{tabular}

The findings of Table 8 shows that many of the municipalities and cities of the province are landlocked. Furthermore, the findings from Table 5 shows that the coastal areas lack water accessibility and support infrastructure. The findings were similar to the study of Olugu \& Onukwube (2012), which revealed that Lagos, Nigeria has low tourist water transport activity.

Table 8 LTA of WTI

\begin{tabular}{llll}
\hline & & $W M$ & $V I$ \\
\hline 1. & small boats & 2.45 & very low \\
2. & other tourist water transport (kayaks, rafts, etc.) & 2.20 & very low \\
& & 2.05 & very low \\
3. yachts & 2.04 & very low \\
$4 . \quad$ ferries & Total & 3.72 & Very Low \\
\hline
\end{tabular}

The TSI lacks tourism activity due to several reasons. The tour guides of tourists are mostly from outside the province. Also, the local tour guides also perform guiding duties outside the province. The registered travel agencies and tour operators are more in number but mostly offers services outside of Cavite. The travel agencies, tour operators and tour guides of the province have fewer accredited tour guides and travel and tour operators compared to the neighboring regions (Department of Tourism, 2009).

Table 9 LTA of TSI

\begin{tabular}{llll}
\hline & & $W M$ & $V I$ \\
\hline 1. & tour guides & 3.30 & Low \\
$2 . \quad$ travel agencies & 3.27 & Low \\
3. tour operators & 3.24 & Low \\
\hline & Total & 3.27 & Low \\
\hline
\end{tabular}

Table 10 LTA of AI

\begin{tabular}{llll}
\hline & & $W M$ & $V I$ \\
\hline 1. & religious and pilgrimage tourism & 3.79 & moderate \\
2. cultural and heritage tourism & 3.64 & moderate \\
3. nature-based tourism & 3.57 & moderate \\
4. & sports and recreation tourism & 3.54 & moderate
\end{tabular}


5. medical and wellness tourism

6. business tourism including MICE

7. agritourism

8. culinary tourism

9. adventure tourism

10. water tourism

$\begin{array}{ll}3.47 & \text { Low } \\ 3.46 & \text { Low } \\ 3.42 & \text { Low } \\ 3.31 & \text { Low } \\ 3.30 & \text { Low } \\ 3.21 & \text { Low } \\ 3.08 & \text { Low }\end{array}$

Development Office, 2013) who does not highlight the churches and pilgrimage of the province. The other variables rated 'moderate' were due to the famous cultural and heritage sites (Emilio Aguinaldo Shrine), popular mountain climbing area (Mt. Pico de Loro), and the established sports and recreation industry (Carmona). gives us a glimpse on the untapped tourism potential in this area. The result refutes the tourism profile of the province (Cavite Provincial Planning and

The overall rating of 'few' among the AI was due to the few popular tourist attractions. Among these known attractions, the most popular is Emilio Aguinaldo Shrine, and some attractions in Tagaytay. Although it can be noted that the highest rated Table 11 Overall LTA

\begin{tabular}{llcc}
\hline & & $W M$ & VI \\
\hline 1. & HRI & 3.72 & Moderate \\
2. & AI & 3.48 & Low \\
3. & TSI & 3.27 & Low \\
4. & LTI & 2.77 & Low \\
5. & WTI & 2.18 & Very Low \\
\hline & Overall Total & 3.08 & Low \\
\hline
\end{tabular}

The findings on Table 11 is consistent with the data of the Department of Tourism \& USAID (2014) and the Cavite Provincial Planning and Development Office (2013) which shows that most of the registered tourism-related establishments in the province belongs to the hotel and restaurant industry.

\section{Impacts of tourism in the Province of Cavite}

The tourism industry is generally viewed to contribute positively to the economy, particularly on the improvement on the local economy and the income. These findings reflect that of the study of De Asis, et al. (2012) whose assessment revealed that the tourism industry has high PEcI in Tagaytay. Among the variables with the highest rating were because of the direct effect to the lowest sector of the economy and the society.

Table 12 PEcI

\begin{tabular}{|c|c|c|}
\hline & $W M$ & $V I$ \\
\hline 1. improves local economy & 3.01 & strongly agree \\
\hline 2. contributes to income and standard of living & 3.00 & strongly agree \\
\hline 3. increases employment opportunities & 2.95 & agree \\
\hline 4. creates new business opportunities & 2.92 & agree \\
\hline 5.5 improves transport infrastructure & 2.91 & agree \\
\hline 5.5 improves investment and development & 2.91 & agree \\
\hline 7. improves public utilities infrastructure & 2.87 & agree \\
\hline 8. increases opportunity for shopping & 2.86 & agree \\
\hline 9. increases tax revenue & 2.85 & agree \\
\hline 10. economic impact is widespread & 2.84 & agree \\
\hline Total & 2.91 & Evident \\
\hline
\end{tabular}


The findings on Table 13 reveals that the residents perceive an increased spending on basic commodities. This result also reflects the findings of De Asis, et al (2012) wherein the NEcI are perceived as high. Both the positive and negative impacts of tourism were rated moderately despite the few level of tourism activity. The findings implies a high multiplier effect of the tourism industry, and a lack of regulation to mitigate the NEcI.

\section{Table 13 NEcI}

\begin{tabular}{|c|c|c|}
\hline & $W M$ & $V I$ \\
\hline 1. increases price of land and housing & 2.83 & agree \\
\hline 2. increases price of goods and services & 2.74 & agree \\
\hline 3. increases cost of living & 2.70 & agree \\
\hline 4. increases road maintenance and transport cost & 2.68 & agree \\
\hline 5. increases potential of imported labor & 2.66 & agree \\
\hline 6.5 increases competition for land & 2.63 & agree \\
\hline 6.5 jobs pay low wages & 2.63 & agree \\
\hline 8. creates seasonal employment & 2.60 & agree \\
\hline 9. profits are exported by non-Cavitenos & 2.59 & agree \\
\hline 10. creates high risk jobs & 2.57 & agree \\
\hline Total & 2.66 & Evident \\
\hline
\end{tabular}

The findings suggests that tourism in the province are highly qualified for educational tours and heritage enrichment. The overall rating supports the findings of Elshiki \& Kaboudi (2011) stating that tourism has a positive impact on the residents' quality of life.

Table 14 PSCI

\begin{tabular}{llcc}
\hline & & $W M$ & $V I$ \\
\hline 1. & facilitates educational experience & 3.02 & strongly agree \\
2. $\quad$ improves quality of life & 3.01 & strongly agree \\
3. contributes to positive changes in values and customs & 2.93 & agree \\
4. promotes cultural exchange & 2.89 & agree \\
5. increases demand for historical and cultural exhibits & 2.87 & agree \\
6. preserves cultural identity of host population & 2.85 & agree \\
7. $\quad$ encourages greater tolerance for social differences & 2.80 & agree \\
8. $\quad$ satisfies psychological needs of people & 2.79 & agree \\
\hline & Total & 2.90 & Evident \\
\hline
\end{tabular}

Table 15 NSCI

\begin{tabular}{llc}
\hline & & \\
\hline 1. & displaces residents for tourism development & VI \\
2. encourages excessive drinking and alcoholism & 2.51 & agree \\
4. encourages excessive gambling & 2.46 & disagree \\
4. effects language and culture negatively & 2.37 & disagree \\
4. creates unwanted lifestyle changes among locals & 2.37 & disagree \\
$6 . \quad$ exclude locals from natural resources & 2.37 & disagree \\
7.5 increases crime and drugs & 2.35 & disagree \\
7.5 increases smuggling & 2.32 & disagree \\
9.5 increases prostitution & 2.32 & disagree \\
9.5 changes values and customs negatively & 2.31 & disagree \\
\hline Total & 2.31 & Slightly Evident \\
\hline
\end{tabular}


Table 15 shows that tourism is seen as a 'clean' and wholesome industry. This further implies that tourism in the province has been developed as a familyfriendly destination. This is due to the various laws among cities and municipalities that prohibits unwholesome activities. The findings mirrors the results of Monterrubio, Gullette, Ontiveros, Fernandez, \& Luque's (2012) findings which stated that tourism does not contribute to crime, prostitution or drug.

Table 16 PEnI

\begin{tabular}{|c|c|c|}
\hline & $W M$ & $V I$ \\
\hline 1. improves cleanliness & 3.08 & $\begin{array}{c}\text { Strongly } \\
\text { agree }\end{array}$ \\
\hline 2. preserves historical sites & 3.07 & $\begin{array}{c}\text { Strongly } \\
\text { agree }\end{array}$ \\
\hline $\begin{array}{l}\text { 3. improves areas' } \\
\text { appearance }\end{array}$ & 3.06 & $\begin{array}{c}\text { Strongly } \\
\text { agree }\end{array}$ \\
\hline $\begin{array}{l}\text { 4. protects the natural } \\
\text { environment }\end{array}$ & 3.02 & $\begin{array}{c}\text { Strongly } \\
\text { agree }\end{array}$ \\
\hline Total & 3.06 & Evident \\
\hline
\end{tabular}

The findings in Table 16 shows that, despite the problems on solid waste disposal, the major attractions are kept clean and presentable. The findings further implies that the environmental management among the sites and destinations in Cavite are good. Mensah (2012) has stated that tourism has contributed to the positive image of a destination, in which case is applicable to most of the key attractions in the province.

Table 16 NEnI

\begin{tabular}{lll}
\hline & $W M$ & VI \\
\hline 1. increases air pollution & 2.62 & agree \\
2. decreases open space & 2.61 & agree \\
3.5 increases solid waste & 2.59 & agree \\
pollution & & agree \\
3.5 increases noise pollution & 2.59 & agree \\
5. increases water pollution & 2.55 & disagree \\
6. natural landscape is lost & 2.49 & \\
$\quad$ to tourism development & & disagree \\
7. contributes to water & 2.46 & disagree \\
$\quad \begin{array}{l}\text { shortage } \\
\text { 8. destroys flora and fauna }\end{array}$ & 2.44 & disagree \\
9. degrades landscape and & 2.43 & disagree \\
$\quad$ historic sites & 2.41 & Evident \\
10. disrupts wildlife & 2.52 & \\
\hline
\end{tabular}

The findings revealed that most of the environmental problems are pollution-related. The findings indicate that pollution and congestion are the first aspect to be affected in a tourism activity. The findings supports the argument that tourism contributes to traffic, noise, and littering (Monterrubio, Gullette, Ontiveros, Fernandez, \& Luque, 2012).

Table 17 Overall IOT

\begin{tabular}{llll}
\hline & & $W M$ & $V I$ \\
\hline 1. & PEnI & 3.06 & Evident \\
2. & PEcI & 2.91 & Evident \\
3. & PSCI & 2.75 & Evident \\
4. & NEcI & 2.66 & Evident \\
5. & NEnI & 2.52 & Evident \\
6. & NSCI & 2.33 & Slightly \\
& & & Evident \\
\hline
\end{tabular}

The findings on Table 18 confirms the findings of Vareiro, Remoaldo \& Ribeiro (2012) wherein residents perceive lower negative impact of tourism development, especially if the destination is in its not yet fully developed. Moreover, the finding implies that the current tourism practices are more beneficial than detrimental to the economy, society, and the environment.

\section{Effect of QTR and LTA to the IOT}

The quality of CAR and HR, and the LTA of the HRI are the best predictors for the positive economic impacts. The quality of the CAR are often the benchmark for a healthy economy. The quality of HRis directly linked to the employment and income which are also benchmark for economic development. Meanwhile, the HRI, being the most in number among all the tourism-related establishments, contributes a lot to salary, tax, employment, and development. 


\begin{tabular}{|c|c|c|c|c|c|}
\hline \multirow[b]{2}{*}{ predictors } & \multicolumn{2}{|c|}{ unstandardized coefficients } & \multirow{2}{*}{$\begin{array}{c}\text { standardized } \\
\text { coefficients } \\
\text { beta }\end{array}$} & \multirow[b]{2}{*}{$t$} & \multirow[b]{2}{*}{ sig } \\
\hline & $b$ & std. error & & & \\
\hline (Constant) & .977 & .079 & & 12.366 & .000 \\
\hline CAR & .294 & .029 & .381 & 9.967 & .000 \\
\hline HR & .209 & .029 & .282 & 7.111 & .000 \\
\hline HRI & .081 & .017 & .151 & 4.817 & .000 \\
\hline
\end{tabular}

The quality of HR and CAR, and the level of activity of the HRI have significant effect to the NEcI. The findings implies that the increase in prices of land, basic commodities, and cost of living is attributed to the development of CAR and the increase of the number of hotels and restaurants. Moreover, the tourism industry requires many types of skill sets that usually prompts the industry to import labor. In this case, the need to import labor contributes to the leakage.

Table 19 Regression analysis of the NEcI

\begin{tabular}{|c|c|c|c|c|c|}
\hline \multirow[b]{2}{*}{ predictors } & \multicolumn{2}{|c|}{ unstandardized coefficients } & \multirow{2}{*}{$\begin{array}{c}\text { standardized } \\
\text { coefficients } \\
\text { beta }\end{array}$} & \multirow[b]{2}{*}{$t$} & \multirow[b]{2}{*}{ sig } \\
\hline & $b$ & std. error & & & \\
\hline (Constant) & 1.413 & .110 & & 12.906 & .000 \\
\hline Human Resources & .189 & .041 & .234 & 4.632 & .000 \\
\hline $\begin{array}{l}\text { Hotel and Restaurant } \\
\text { Industry }\end{array}$ & .094 & .023 & .161 & 4.038 & .000 \\
\hline Capital Resources & .089 & .041 & .106 & 2.189 & .000 \\
\hline
\end{tabular}

The regression model in Table 20 shows that the HR, capital resources, CAR, and the level of activity of the HRI are predictors to PSCI. The results implies good socio-cultural practices among the given predictors. The HR and CAR are benchmark for healthy society and culture respectively. Also, the recent development in the CAR of the province are geared towards improving the quality of life of the residents. Furthermore, the HRI facilitates host population and tourist interaction.

Table 20 Regression analysis of the PSCI

\begin{tabular}{lccccc}
\hline \multicolumn{5}{c}{ unstandardized coefficients } & $\begin{array}{c}\text { standardized } \\
\text { coefficients } \\
\text { predictors }\end{array}$ \\
\hline (Constant) & $b$ & std. error & beta & $t$ & sig \\
HR & 1.175 & .092 & & 12.705 & .000 \\
CAR & .181 & .038 & .240 & 4.731 & .000 \\
CUR & .218 & .034 & .277 & 6.386 & .000 \\
HRI & .081 & .034 & .110 & 2.366 & .018 \\
\hline
\end{tabular}

The LTA on LTI, and the quality of HR and NR contributes to the NSCI, as shown in Table 21. However, the quality of AI offsets the perception of the negative impacts, because the highest rated attractions those that are cultural in nature. The negative effect of the LTI may be attributed to its contribution to traffic, especially on areas with many tourists. The negative effects of the quality of HR may be due to the many employees of tourism establishments that has to travel long distance, which prompts many to rent a boarding house. The effect of the NR implies that locals are excluded or even displaced from areas with high quality of NR. This is true especially in Tagaytay, whose prime locations are mostly privately owned.

Table 21 Regression analysis of the NSCI 


\begin{tabular}{|c|c|c|c|c|c|}
\hline \multirow[b]{2}{*}{ predictors } & \multicolumn{2}{|c|}{ unstandardized coefficients } & \multirow{2}{*}{$\begin{array}{c}\text { standardized } \\
\text { coefficients } \\
\text { beta }\end{array}$} & \multirow[b]{2}{*}{$t$} & \multirow[b]{2}{*}{ sig } \\
\hline & $b$ & std. error & & & \\
\hline (Constant) & 1.541 & .104 & & 14.751 & .000 \\
\hline LTI & .155 & .033 & .241 & 4.656 & .000 \\
\hline HR & .123 & .037 & .151 & 3.319 & .001 \\
\hline NR & .110 & .034 & .153 & 3.195 & .001 \\
\hline AI & -.084 & .036 & -.139 & -2.353 & .019 \\
\hline
\end{tabular}

The findings on Table 22 shows that the quality of CAR and the LTA of the HRI contributes to the PEnI. This can be attributed to the orderliness and cleanliness of the surroundings among the HRI.
Furthermore, the findings suggests that the employees are well-informed and trained in making the area clean and physically appealing.

Table 22 Regression analysis of the PEnI

\begin{tabular}{lccccc}
\hline \multicolumn{1}{c}{ unstandardized coefficients } & $\begin{array}{c}\text { standardized } \\
\text { coefficients } \\
\text { predictors }\end{array}$ & \multicolumn{1}{c}{ std. error } & beta & $t$ & sig \\
\hline (Constant) & 1.202 & .102 & & 11.764 & .000 \\
CAR & .363 & .038 & .413 & 9.529 & .000 \\
HR & .147 & .038 & .174 & 3.867 & .000 \\
HRI & .049 & .022 & .081 & 2.271 & .023 \\
\hline
\end{tabular}

Table 23 suggests that the NEnI are caused by the quality of the CUR and NR, and the LTA of the LTI and HRI. The higher the quality of the NR, the higher the perceived negative effect on the environment, which means that the locals perceive more pollution on areas with high value NR. Meanwhile, the AI has an inverse effect on the perceived NEnI which suggests that the attractions in the province have effective programs in managing pollution.

Table 23 Regression analysis of the NEnI

\begin{tabular}{|c|c|c|c|c|c|}
\hline \multirow[b]{2}{*}{ predictors } & \multicolumn{2}{|c|}{ unstandardized coefficients } & \multirow{2}{*}{$\begin{array}{c}\text { standardized } \\
\text { coefficients } \\
\text { beta }\end{array}$} & \multirow[b]{2}{*}{$t$} & \multirow[b]{2}{*}{ sig } \\
\hline & $b$ & std. error & & & \\
\hline (Constant) & 1.708 & .121 & & 14.089 & .000 \\
\hline CUR & .153 & .044 & .175 & 3.516 & .000 \\
\hline LTI & .099 & .040 & .138 & 2.470 & .014 \\
\hline AI & -.142 & .043 & -.212 & -3.324 & .001 \\
\hline NR & .110 & .039 & .138 & 2.807 & .005 \\
\hline HRI & .070 & .033 & .108 & 2.105 & .036 \\
\hline
\end{tabular}

Table 24 shows that tourism has more positive impacts than negative impacts. The findings mirrors the study of Vareiro, Remoaldo \& Ribeiro (2012) which revealed that residents perceive lower negative impacts of tourism development. This also suggests the need to improve existing tourism-related policies and programs to help enhance the positive impacts, while mitigating the negative ones.

Table 24 Model summary of the dependent variables 


\begin{tabular}{|c|c|c|c|c|}
\hline dependent variables & $r$ & r square & $\begin{array}{l}\text { adjusted } r \\
\text { square }\end{array}$ & $\begin{array}{c}\text { std. error of the } \\
\text { estimate }\end{array}$ \\
\hline 1. $\quad$ PEcI & .492 & .492 & .490 & .5017 \\
\hline 2. PSCI & .602 & .362 & .359 & .573914 \\
\hline 3. PEnI & .592 & .351 & .348 & .648 \\
\hline 4. NEcI & .424 & .179 & .176 & .695 \\
\hline 5. NSCI & .351 & .123 & .118 & .723 \\
\hline 6. NEni & .301 & .091 & .084 & .8208 \\
\hline
\end{tabular}

Table 25 shows that the HR has the widest scope and the highest cumulative impact $(\mathrm{B}=.849)$. However, the CAR contributes the most to the total positive impact $(\mathrm{B}=.581)$, while the quality of $\mathrm{HR}$ contributes the most to the negative impacts $(\mathrm{B}=$ .312). Only the AI has an inverse effect to the tourism impacts. It can also be noted that the HRI, although with only moderate impact, has a wide scope. These data can be used by the provincial and local government offices to help them focus their development based on which area of sustainability they want to focus.

Table 25 Model summary of the independent variables

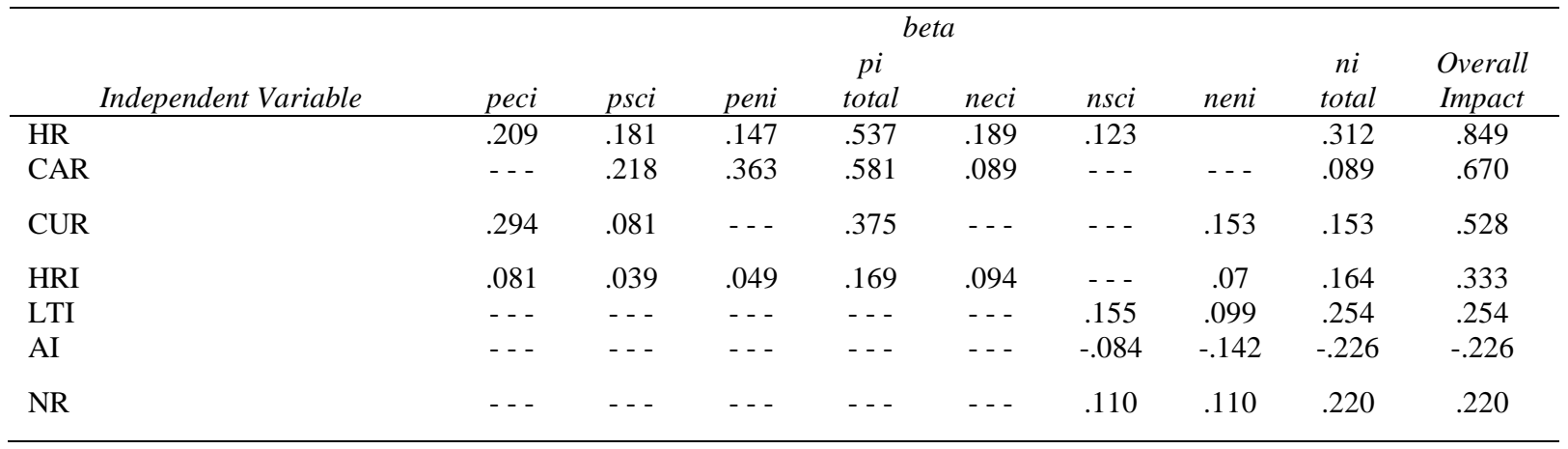

\section{CONCLUSIONS AND RECOMMENDATIONS}

The development needs of the tourism industry of the province of Cavite are few, but significant. Furthermore, the tourism industry of the province has yet to achieve its full potential, as evidenced by the average tourism activity and moderate tourism impacts. Presently, the tourism industry cannot compete against more established tourist destination when considering the overall quality of tourism resources. However, the province can boast of its good historical sites. The overall practices of the tourism industry is presumed to be above average, as evidenced by a higher positive impact compared to the negative impact, although these practices still be significantly improved. The tourism industry also has a significant contribution to the positive and negative economic, socio-cultural, and environmental impacts.

This researchers created sustainable tourism development plan for the province of Cavite, and highly recommends its use and implementation. The proponents also recommends creating a sustainable tourism development plan for each city and municipality. The data gathered can be isolated, recomputed and be made specific for each city and municipality. Further recommendations include a study on budget, and a marketing plan that may be applied together with the proposed tourism development plan.

\section{ACKNOWLEDGMENT}

The proponents would like to thank De La Salle University - Dasmarinas, through the University Research Office for funding this study.

\section{REFERENCES}

Ballantyne, R., Packer , J. \& Axelsen, M. (2009). Trends in tourism research. Annals of Tourism Research, 36, $149-$ 152. doi:10.1016/j.annals.2008.07.001

Bharwani, S., \& Butt, N. (2012). Challenges for the global hospitality industry: an HR perspective. Worldwide Hospitality and Tourism Themes, 4(2), 150-162. doi: http://dx.doi.org/10.1108/17554211211217325

Bunruamkaew, K. \& Murayama, Y. (2012). Land use and natural resources planning for sustainable ecotourism using GIS in Surat Thani, Thailand. Sustainability, 4(3), 412-429. doi: $10.3390 / \mathrm{su} 4030412$ 
CALABARZON Regional Development Plan. (2011). Retrieved from http://issuu.com/cap-dis/docs/region_4a

Calabro, F., \& Spina, L. D. (2013). The cultural and environmental resources for sustainable development of rural areas in economically disadvantaged contexts. Economic appraisals issues of a model of management for the valorization of public assets. Advanced Materials Research, 869-870, 43-48. doi: 10.4028/www.scientific.net/AMR.869-870.43

Calgaro, E., Howes, D. D., \& Lloyd, K. (2013). Application of the Destination Sustainability Framework to explore the drivers of vulnerability and resilience in Thailand following the 2004 Indian Ocean Tsunami. Journal of Sustainable Tourism. 22, 361-383. doi:10.1080/09669582.2013.826231

Cavite Provincial Planning and Development Office. (2013). Cavite socio economic and physical profile 2013. Retrieved

from http://www.cavite.gov.ph/home/index.php/generalinformation/socio-economic-profile/socio-economic-andphysical-profile-2012

Cavite Tourism Provinvial Board Inc. (2010). Cavite tourism plan enriching Cavite's tourism. Source: http://www.cavitetourismboard.org/news.php?news_id=11 \&start $=0 \&$ category_id=0\&parent_id=0\&arcyear $=\& \operatorname{arcmon}$ th

Cruz, Z. L. (2011). Tourism planning and development. Mandaluyong City. National Book Store.

De Asis, A., Alfraro, B., De Ramos, J., Ermita, J. E., Maglaqui, J., Sanchez, K. E., Sierra, S. (2012). Impact of hospitality development to the residents of Tagaytay City: basis for a proposed sustainable plan (Undergraduate Thesis).

Department of Tourism \& USAID. (2014). Gender toolkit for tourism. Retrieved from dot.gov.ph

Department of Tourism. (2009). List of accredited establishments and individuals. Retrieved from: http://accreditationonline.tourism.gov.ph/Pages/Portal/Porta IListFrontliners.aspx

Department of Tourism. (2011). The national tourism development plan: strengthening the Philippines strategic planning process. Retrieved from asiapacific.unwto.org/sites/all/files/pdf/philippines_5.pdf

Department of Tourism. (2012). Tourism development planning guidebook for local government units 2012 edition. Retrieved from http://www.tourism.gov.ph/SitePages/PublicationsDownloa ds.aspx

Department of Tourism. (2012, August). Report on the regional distribution of travelers. Retrieved from: dot.gov.ph

Department of Tourism. (2012, June). Number of establishments and rooms by province. Retrieved from: dot.gov.ph

Department of Tourism. (2013). Survey on the comparative monthly average occupancy rates \& length of stay (in nights) of guest of accredited and non-accredited hotels in Metro Manila January - December 2013. Retrieved from dot.gov.ph
Eshliki, S. A., \& Kaboudi, M. (2011). Community perception of tourism impacts and their participation in tourism planning: a case study of Ramsar, Iran. Procedia Social and Behavioral Sciences, 36, 333-341. doi:10.1016/j.sbspro.2012.03.037

Firoiu, D., \& Croitoru, A. (2013). Tourism and tourism infrastructure from the perspective of technological changes. Romanian Economic and Business Review, 8(2), 93-103. Retrieved from http://www.rebe.rau.ro/REBE\%208\%202.pdf\#page=93

Jalilian, M. A., Danehkar, A., \& Ali Fami, H. S. (2012). Determination of indicators and standards for tourism impacts in protected Karaj River, Iran. Tourism Management, 33, 61-63. doi: 10.1016/j.tourman.2011.01.024

Komppula, R. (2012). The role of individual entrepreneurs in the development of competitiveness for a rural tourism destination - A case study. Tourism Management. 40, 361371. doi: 10.1016/j.tourman.2013.07.007

Korstanje, M. (2012). Reconsidering cultural tourism: an anthropologist's perspective. Journal of Heritage Tourism. 7(2), 179-184. doi: 10.1080/1743873X.2011.639883

Kreag, G. (2001). The impacts of tourism. Minnesota Sea Grant. Retrieved from www.seagrant.umn.edu

Lee, T. H. (2013). Influence analysis of community resident support for sustainable tourism development. Tourism Management. 34, 37-46. doi:10.1016/j.tourman.2012.03.007

Mensah, C. (2012). Residents' perception of socioeconomic impacts of tourism in Tafi Atome, Ghana. Asian Social Science, 8, 15. doi: 10.5539/ass.v8n15p274

Monterrubio, J. C., Gullette, G. S., Ontiveros, M. M., Fernandez, M. J., \& Luque, A. C. (2012). Social impacts of tourism as perceived by state-planned tourism destination residents: the case of Huatulco, Mexico. International Journal of Tourism Anthropology, 2, 1. doi: 10.1504/IJTA.2012.046094

Notorio, P. A. (2010).Tourism development plan of Lubang, Occidental Mindoro (Master's thesis).

Olugu, N. U. \& Onukwube, H. N. (2012). Exploring the coastal tourism potentials of Lagos. Journal of Sustainable Development, 5(7). Retrieved from: http://www.ccsenet.org/journal/index.php/jsd/article/view/1 4777

Pyo, S. (2012). Identifying and prioritizing destination knowledge needs. Annals of Tourism Research. 39, 11561175. doi:10.1016/j.annals.2011.12.009

Republic Act 9593 (2009). Retrieved from http://www.gov.ph/2009/11/10/implementing-rules-andregulations-of-republic-act-no-9593/

Ruhanen, L. (2012). Local government: facilitator or inhibitor of sustainable tourism development? Journal of Sustainable Tourism. 21, 80-98. doi: 10.1080/ 09669582.2012.680463

Sisson, L. G., \& Adams, A. R. (2013). Essential hospitality management competencies: the importance of soft skills. Journal of Hospitality and Tourism Education, 25(3), 131145. doi: 10.1080/10963758.2013.826975 
Stynes J. \& O'Halloran, C. (2004). Tourism planning. Michigan State University Cooperative Extension Service

Suh, E., West, J. J., \& Shin, J. (2012). Important competency requirements for managers in the hospitality industry. Journal of hospitality, leisure, sport \& tourism education. 11(2), 101-112. doi: 10.1016/j.jhlste.2012.02.005Tabuyo, J. (2010). Tourism strategies towards creating northern Cagayan as tourism hub in Region 2 (Master's thesis)

The World Economic Forum. (2013). The travel and tourism competitiveness report 2013. Retrieved from: www.weforum.org/reports/travel-tourism-competitivenessreport-2013

Vareiro, L. M., Remoaldo, P. C., \& Ribeiro, J. A. (2012). Residents' perceptions of tourism impacts in Guimaraes (Portugal): a cluster analysis. Current Issues in Tourism, 16, 535-551. Retrieved from: http://www.tandfonline.com/doi/abs/10.1080/13683500.201 2.707175\#.VVLA7buJiW8 